\title{
THE LEXICON OF ENGLISH PHILOSOPHY IN THE PLANE OF THE PHILOSOPHY OF THE LANGUAGE
}

\author{
Denis Bakhtiyorovich Sadullaev \\ English Chair, Bukhara State Medical Institute, Uzbekistan
}

\section{ABSTRACT}

The article makes an attempt to hermeneutic interpretation of the problem of the specificity of the formation, and further evolution of the vocabulary of the English philosophy of the Renaissance period from the point of view of the philosophy of language. The authors give their interpretation of this problem in two aspects - philosophical and lexical with the involvement of a large amount of factual material, as well as identifying the role and significance of philosophical and worldview knowledge in the formation of a system of categories of English philosophy in the light of the formation of the principles of scientific knowledge and the genesis of scientific knowledge itself; interesting moments here are associated with an attempt to identify the specifics and national originality of the formation of the system of categories of English philosophical thought, the definition of its properties.

KEYWORDS:- Lexicon, system, worldview, Renaissance, formation, conception.

\section{INTRODUCTION}

It is generally accepted that philosophy proceeds from the recognition of the movement and development of the external world and human thinking as a result of the synthesis of existing external and internal contradictions. This provision is fully applicable in relation to language. Meanwhile, many problems associated with the development and movement of the language system still remain unresolved, namely:

a) the scale and nature of changes in concepts in the language system in general are poorly studied;

b) the internal mechanism of the evolution of the philosophical terminological system of the English language has not been studied at all.

There are literally few complex scientific studies devoted to this serious problem, since changes occurring over a relatively short time are much more difficult to detect than others: they are minimal in volume, proceed quickly and, for this reason, are practically indistinguishable. At the same time, when comparing several time slices separated by centuries, it is much easier to detect significant qualification-quantative changes. Consequently, the appeal to the littlestudied area of dynamic phenomena observed in the formation of the lexicon of philosophy at the moment seems to be very relevant, in particular, from the point of view of the philosophy of language. The principle of historicism, the recognition of the fact that the history of philosophy is closely and organically linked with the history of production, culture, science, technology, with the history of social worldviews, determines another aspect of the relevance of the article. Therefore, the main 
CURRENT RESEARCH JOURNAL OF PEDAGOGICS 2(11): 41-46, November

2021 DOI: https://doi.org/10.37547/pedagogics-crjp-02-11-10

ISSN 2767-3278

(C)2021 Master Journals

Crossref do: 81 Google

Accepted 25th November, 2021 \& Published 30 ${ }^{\text {th }}$ November, 2021

purpose of this article is to analyze the mechanism of the "entry" of ideas and concepts into the network of categorical structures of the philosophical conceptual apparatus, i.e. identifying the role and significance of philosophical and worldview knowledge in the formation of a system of categories in English philosophy in the light of the formation of the principles of scientific knowledge and the genesis of scientific knowledge proper; an attempt to identify the specifics and national originality of the formation of the system of categories of English philosophical thought, the definition of its properties.

\section{Methods}

Any philosophical text is an internally dialogical structure, containing both explicit and implicit appeals to the opponent by one author, directed against the views of others, based on known facts and propositions or questioning them. It is no coincidence that, striving to achieve maximum expressiveness and reduce the likelihood of inadequate perception, philosophers set out the ideas, statements, speculations they received as a result of reasoning, in the form of an internal dialogue with an imaginary interlocutor.

As for the specific philosophy of the research period - the late Renaissance (late XYI - early XYII centuries), it "acquired a fundamentally asystematic character, it gravitated towards a form of dialogue. It was journalistically active and developed as an interpretation of certain routinely pressing problems $[1, \mathrm{p} .82]$ Colliding different points of view, they strive in this way to stimulate the emergence of new knowledge in this "interlocutor." The method of Socratic dialectics, which helps to understand the truth with the help of dialectical reasoning, turned out to be, apparently, effective for the philosophy of empiricism in the era of the late Renaissance. Samples of texts constructed in this way by thinkers of the Renaissance can be found at all separate stages of the study period. Moreover, their authors are not only philosophers, but also often natural scientists, experimental scientists, writers, poets, statesmen (let's call at least Galileo's "Dialogue on the two main systems of the world - Ptolemaic and Copernicus", Francis Bacon "New Organon", T. Mora's "Polemics with Luther", "Polemics with English Reformers" by D. Scott, works of W. Shakespeare, E. Spencer, F. Sydney, D. Donne). With the help of such a "dialogue" model, it became possible to more easily solve the problem of assimilating new knowledge. "At critical stages, the history of philosophy reaches the heights of comprehension of the world and finds itself in a state of dramatic rupture with the world and with itself. The contradictory nature of its state becomes unbearably acute when a break in the self-movement of society, its transition from one qualitative state to another coincides in time with a break in the culture of the people, the rejection of recently revered spiritual values and the painful formation of new ones "[2, p. 4].

The English philosophers of the period, criticizing the reality of their day, it was in this connection that they developed their concepts, substantiating either the validity of their criticism, or their social ideal, or some other issues. Another feature of the philosophical works of the period is the tremendous attention of thinkers to the problems of the simplest certainties, their desire to "solitary, in an armchair silence, allowing only scholarly correspondence, to meticulously investigate the question of the fundamental foundations of knowledge" [2, p.82; 3, c.63].

It should be noted that interest in the English national language, in its history and, more broadly, in the history of the English national culture, is almost not observed in England during the Middle Ages and later. It is characteristic that Bolton W.F. and Tucker S.I. (Tucker SI) - Authors 
CURRENT RESEARCH JOURNAL OF PEDAGOGICS 2(11): 41-46, November

2021 DOI: https://doi.org/10.37547/pedagogics-crjp-02-11-10

ISSN 2767-3278

(C)2021 Master Journals

\section{Crossref do) 8 Google}

Accepted 25th November, 2021 \& Published 30 ${ }^{\text {th }}$ November, 2021

of highly reputable books on English learning of their own language, citing evidence from no earlier than the late 15 th century or early 17 th century (See: Bolton WF The English Language Essays and American men of letters , 1490-1839. - Cambridge Univ. Press 1966; Tucker SI English examined. Two centuries of comment on the mother tongue. - Cambridge, 1961).

Only in the second half of the 16th century and the first half of the 17th century in England there is a serious interest in the native language, its history and the history of ancient national literature. It was during this period that an intensive study of the history of the English language began, in particular its etymology, which, however, boiled down to the search for an etymone in classical languages. The first attempts to draw attention to the history of their native language are observed in England since the second half of the 16th century: the first book with texts in Old English appears "Proof of the Antiquity of the Church in England" (1567), the first etymological dictionary of the English language by J. Minshu (1617) " Ductor in linguas ", Williams Somner's Dictionary of Old English Dietionarium Saxonico-Latino-Anglicum" (1659), Grammar of Old English by J. Hickes "Institutiones grammaticae Anglo-Saxonical et Moeso-Gothicae" (1689).

For the transmission of philosophical concepts, it mainly promotes the perception of them as terms. These words, as conceived by the authors who used them, had a greater semantic volume compared to the primordial words, which, due to a longer stay on English soil (if it is a borrowing) or its primordiality (by origin), was the main psychological barrier. It was believed that the primordial vocabulary was not capable of expressing with its semantic field the wealth of new scientific concepts in the light of the new perception of the world and the achievements of experimental sciences. This leads to an essential conclusion: the formation of new conceptual units from primordial elements, as well as the actualization of one of the meanings of words of primordial origin that were already in use on English soil in the 14th-16th centuries, does not attract the attention of native speakers and, above all, philosophers.

Actualization of one of the variants of the original words serves more to explain or introduce new borrowings, mainly from Latin, into everyday life. At first glance, such a turnover seems illogical, because the original word - the ideographic embodiment of the concept - should be closer to both the philosopher and the reader, since it comes from the elements of their native language. But the "artificiality" of the formation of such lexical units and, to a certain extent, the cumbersomeness of their graphic design, and most importantly, the burden of the semantic volume of previous centuries and the inaccessibility, due to this, of a new meaning, involuntarily gives way to a borrowed word: a new concept in the light of a new worldview is always interesting and can be explained with the help of a new unit precisely because it is new, since the level of consciousness of native speakers is also higher.

\section{Conclusion}

Philosophical concepts are not only awakened to life by ideological needs, they essentially reflect these needs in their results. Generated by a concrete historical situation, the philosophical system reflects it at an extremely high level of abstraction. Each philosophical teaching, school develops, as a rule, its own specific language. An important point here is mastering this specific language, because analyzing, or rather, penetrating into the world of ideas and concepts of the thinker, we assimilate and then interpret the point of view of this thinker, reveal linguistic erudition, vocabulary richness and conceptual apparatus presented in the works of the 
CURRENT RESEARCH JOURNAL OF PEDAGOGICS 2(11): 41-46, November

2021 DOI: https://doi.org/10.37547/pedagogics-crjp-02-11-10

ISSN 2767-3278

(C)2021 Master Journals

Crossref do: 81 Google

Accepted $25^{\text {th }}$ November, 2021 \& Published $30^{\text {th }}$ November, 2021

philosopher in a systematized form, the semantics of the units of which concentrated the achievements of the philosophical thought of a particular doctrine.

To trace the development of the categories of thinking at the stage of their formation as categories of philosophy, it is necessary to study the evolution of the meanings of the words expressing them and grammatical structures in the culture of the native people of the language in question over a long historical period.

\section{REFERENCES}

1. Soloviev E.V. Philosophy or Pseudophilosophy? / Philosophical Consciousness: The Dramaticism of Renewal. - M., 1991. - p.71-93.

2. Philosophical consciousness: the drama of renewal. - M., 1991. - 453 p.

3. Kudryashev A.F. Correlation of ontology and epistemology / Philosophy in a globalizing world. Issue1. -Ufa: RITs BashGU, 2017. p.63-68.

4. From the history of political and legal doctrines of the XVII-XVIII centuries. - M., 1989 -- $448 \mathrm{p}$

5. Stenin V.S. Formation of scientific theory. Minsk, 1976.-320 p.

6. Mikhalenko Yu.P. F. Bacon and his doctrine. - M .: Science. 1975 .-- 264 p.

7. Sadullaev D. B. Philosophical understanding of terms and concepts by an author as an object of linguistic investigations //Молодой ученый. 2020. - №. 22. - С. 627-631.

8. Sadullaev D. B. (2020). Historical reality concepts. ISJ Theoretical \& Applied Science, 04 (84), pp. 414- 419
9. Sadullaev Denis Bakhtiyorovich 2020. Concerning the history, formulation and interpretation of the conversion's issue in english language. International Journal on Integrated Education. 3, 3 (Mar. 2020), 9597.

DOI:https://doi.org/10.31149/ijie.v3i3.96.

10. Sadullaev D. B., Ostonova S. N., Shodiev S. S. Interpretation of philosophical terms and concepts as an essential subject for linguistic researches of xix-xx centuries, held in Russia and Europe // ACADEMICIA: An International Multidisciplinary Research Journal. Year : 2020, Volume : 10, Issue : 10, First page : ( 590) Last page : ( 598), Online ISSN : 2249-7137. Article DOI : 10.5958/2249-7137.2020.01171.4

11. Sadullaev, Denis Bakhtiyorovich Terminology as a separate scientific field and its actual position in modern linguistics // ACADEMICIA: An International Multidisciplinary Research Journal. Year : 2020, Volume : 10, Issue : 11, First page : (1964) Last page : (1973), Print ISSN : 0000-0000. Online ISSN : 2249-7137. Article DOI : 10.5958/22497137.2020.01486.X

12. Sadullaev, Denis B. "Problems of Understanding Philosophical Text as a Linguistic Phenomenon." JournalNX, vol. 6, no. 06,2020 , pp. $128-136$.

13. Шадманов Курбан Бадриддинович, \& Садуллаев Денис Бахтиерович (2019). Из истории становления системы основных понятий английской философии. Наука и образование сегодня, (10 (45)), 40-43.

14. Садуллаев Д. Б. Форма существования языка //81.2 г (5У) Ш 16. - 2019. - С. 201.

15. Sadullaev Denis Bakhtiyorovich Linguistic combinatory processes "assimilation" and 
CURRENT RESEARCH JOURNAL OF PEDAGOGICS 2(11): 41-46, November

2021 DOI: https://doi.org/10.37547/pedagogics-crjp-02-11-10

ISSN 2767-3278

(C)2021 Master Journals

\section{Crossref do) 8 Google}

Accepted 25th November, 2021 \& Published 30 ${ }^{\text {th }}$ November, 2021

"borrowing" as a basis for the development of modern english terminology // Asian Journal of Multidimensional Research (AJMR). Year : 2020, Volume : 9, Issue : 11, First page : ( 33) Last page : (38), Online ISSN : 2278-4853. Article DOI : 10.5958/2278-4853.2020.00297.9

16. Shadmanov Kurban Badriddinovich, Sadullaev Denis Bakhtierovich From the history of the formation of the system of basic concepts of English philosophy // Science and education today. 2019. No. 10 (45). URL: https://cyberleninka.ru/article/n/izistorii-stanovleniya-sistemy-osnovnyhponyatiy-angliyskoy-filosofii

17. Obidovna, D. Z., \& Sadullaev Denis. (2021). Formulas of speech etiquette in a genderengineered communication strategy. Central asian journal of theoretical \& appliedsciences,

http://cajotas.centralasianstudies.org/ind ex.php/CAJOTAS/article/view/180

18. Bakhtiyorovich, S. D. (2021). Term: definition of the concept and its essential features. Central asian journal of theoretical \& applied sciences, 2(6), 12-18. http://cajotas.centralasianstudies.org/ind ex.php/CAJOTAS/article/view/181

19. Бахтиерович, С. Д. (2021). Терминологические единицы сквозь призму комбинаторно-компонентного и функионально-синтаксического анализа. Central asian journal of theoretical \& applied sciences, 2(6), 23-29. http://cajotas.centralasianstudies.org/ind ex.php/CAJOTAS/article/view/183

20. Sadullaev, D. B. (2021). Renaissance And Renaissance Philosophical Texts Through The Prism Of Historical Approach. The American Journal of Social Science and
Education Innovations, 3(05)

21. Садуллаев Д. Б. Philosophical understanding of terms and concepts by an author as an object of linguistic investigations //Молодой ученый. 2020. - №. 22. - С. 312.

22. Sadullaev D. B. (2020). Concerning the history, formulation and interpretation of the conversion's issue in english language. International Journal on Integrated Education, 3, 3 (Mar. - 2020

23. Бахтин M. M. Проблемы поэтики Достоевского. М.: Советский писатель, 2013. 364 c.

24. Лансон Г. Метод в истории литературы / Пер. и послесл. М. Гершензона. М.: Товарищество Мир, 1911. 428 с.

25. Лихачев Д. С. Древнеславянские литературы как система // VI Международный съезд славистов. Прага, 2015. С. 3-10

26. Shahobiddin Sharofiddinivich Shodiev Islam in the evolution of social and political views of the Uzbek Jadids, their role in the formation of the idea of National Independence // central asian journal of social sciences and history. - Feb. 2021. №VOLUME: 02 ISSUE: 02. - C. 45-50.

27. 27. Shahob Sharofitdinovich Shodiev. Academicia An International Multidisciplinary Research Journal "Interpretation of philosophical terms and concepts as an essential subject for linguistic researches of xix-xx centuries,held in russia and Europe" 590-98 10.5958/2249-7137.2020.01171.4

28. Shahobiddin Sharofiddinovich Shodiev. Bakaev Najmiddin Bakaevich. expressions.. (2020). The role of the Latin language in the history of world statehood. 
CURRENT RESEARCH JOURNAL OF PEDAGOGICS 2(11): 41-46, November

2021 DOI: https://doi.org/10.37547/pedagogics-crjp-02-11-10

ISSN 2767-3278

(C)2021 Master Journals

\section{Crossref doi) 8 Google}

Accepted 25 $5^{\text {th }}$ November, 2021 \& Published 30 ${ }^{\text {th }}$ November, 2021

ISJ Theoretical \& Applied Science, 05 (85), 367-372. Soi: http://s-o-i.org/1.1/TAS-0585-71

Doi: https://dx.doi.org/10.15863/TAS Scopus ASCC: 1203. The role of the latin language in the history of world statehood

29. Sh.Sh.Shodiyev. M.N.Khafizova, S.N.Ostonova

N.B.Bakayev. shakespears lexicon: reason word as a design of the concept of the ability of the human mind to abstraction, conclusion " Theoretical and Applied Science, 162-166, 2020

30. Ш.Ш. Шодиев, Д.Я.Шигабутдинова. «Шекспировский лексикон: слово reason как обозначание понятия способности человеческого ума к абстракции умозаключению» Инновационный потенциал развития науки в современном мире, 189-197, 2020

31. General cultural and educational values of ancient-classic latin language $\mathrm{TN}$ Zayniddinovn, SS Sharofiddinovich central asian journal of theoretical \& applied sciences 2 (5), 77-80 2021

32. Islam in the evolution of social and political views of the Uzbek Jadids, their role in the formation of the idea of National IndependenceKB Shadmanov, SS Shodiev, TN Zayniddinovna central asian journal of social sciences and history 2 (2), 44-50 2021

33. Sadullaev, D. B. (2021). Reduction of A Term In A Scientific Theory. The American Journal of Applied Sciences, 3(05), 123131.

https://doi.org/10.37547/tajas/Volume03 Issue 05-19

34. Shodiyev Shaxobiddin Sharofiddinovich, \& Tasheva Nafisa Zayniddinovna. (2021).
The role of the way of the great steppe in the continuity and relationship of the philosophy and culture of the muslim east and the renaissance west. Innovative Academy Research Support Center, 1(3), 9-13.

http://doi.org/10.5281/zenodo.4925956

35. Shodiev Shahobiddin Sharofiddinovich, \& Majitova Nafisa Zokirovna. (2021). Ideas about an ideal person, language, prosperity in the evolution of public and political views of the uzbek jadids of the beginning of the $\mathrm{xx}$ century. Eurasian Journal of Academic Research, 1(3), 5-8. http://doi.org/10.5281/zenodo.4925897 